\title{
THE TURKISH SOAP OPERA INDUSTRY: A CASE STUDY OF THE PORTER MODEL OF NATIONAL ADVANTAGE
}

\author{
Nevin Cavusoglu, James Madison University, U.S.A. \\ Robert Horn, James Madison University, U.S.A. \\ Robert Jerome, James Madison University, U.S.A. \\ David Cavazos, James Madison University, U.S.A.
}

dx.doi.org/10.18374/JIMS-18-1.5

\begin{abstract}
Soap operas have become a phenomenon in Turkey and have captured a worldwide viewing audience. To analyze the main driving forces behind this success, we apply Michael Porter's "diamond of national advantage model" to develop a concise case study. We find that a considerable amount of the success of the Turkish soap opera industry can be explained by the components of the Porter model. One of the important success indicators is the rising per capita GDP in Turkey, which increases the demand for entertainment products. In addition, the already established film industry provided easy access to inputs for production, such as human and physical capital. Government policies have also contributed to the success of the Turkish soap opera industry domestically and abroad. Also important was the strategic planning of the soap industry which included careful preparation of their product for world viewing audiences by taking into account cultural and language differences.
\end{abstract}

Keywords: Porter model, Turkish soap operas, entertainment services, exports, government broadcasting policy 